\title{
Screening for anthelmintic resistance in equid strongyles (Nematoda) in Romania
}

\author{
Mihai Cernea ${ }^{1}$, Romeo T. Cristina ${ }^{2}$, Laura C. Ştefănuţ ${ }^{1}$, Luís M. Madeira de Carvalho ${ }^{3}$, Marian A. Taulescu ${ }^{1}$ and \\ Vasile Cozma ${ }^{1}$ \\ ${ }^{1}$ University of Agricultural Sciences and Veterinary Medicine, Faculty of Veterinary Medicine, Cluj-Napoca, Romania; \\ ${ }^{2}$ Banat University of Agronomical Sciences and Veterinary Medicine, Faculty of Veterinary Medicine, Timişoara, Romania; \\ ${ }^{3}$ Interdisciplinary Centre of Research in Animal Health, Faculty of Veterinary Medicine, University of Lisbon, Lisbon, Portugal
}

\begin{abstract}
Resistance to anthelmintic medication of equid strongyles is a worldwide phenomenon and for this reason systematic investigations of resistant parasite populations are necessary. The purpose of the present study was to investigate the presence and distribution of equid strongyles resistant to the anthelmintics used in Romania, as well as the pre-treatment and post-treatment prevalence of species of strongylid nematodes. The Faecal Egg Count Reduction Test was performed between 2010 and 2013 on a total number of 588 horses and 23 donkeys from 26 locations (subgroups). Animals of the first group (I) consisting of subgroups no. 1-11 were treated with Albendazole (ABZ), those of the second group (II) consisting of subgroups no. 12-23 with Fenbendazole (FBZ), while Ivermectin (IVM) was used on animals of the third group (III) consisting of subgroups no. 24-26. Resistant strongyles have been found in $82 \%$ (average lower limit of the 95\% confidence interval, LCL95\%, was 65) of the total equids from the group treated with ABZ. In the group of horses treated with FBZ, resistant strongyles were identified in 75\% of the subgroups (LCL95\% $=44$ ). No resistant strongyles have been identified in IVM-treated horse groups (LCL95\% =98). The pre-treatment prevalence of the species of the Strongylinae Müller, 1780 was 22\%, whereas that with nematodes of the subfamily Cyathostominae Molin, $186178 \%$. Post-treatment reduction of strongyline nematodes was observed (5\%), which demonstrates the sensitivity of large strongyles to common anthelmintics. The posttreatment prevalence of cyathostomes was of $95 \%$, which proves their resistance, especially to ABZ- and FBZ-based anthelmintics.
\end{abstract}

Keywords: horse, donkey, Strongylinae, Cyathostominae, benzimidazoles, Ivermectin

Resistance to anthelmintic medication of horse strongyles, especially of those belonging to the subfamily Cyathostominae Molin, 1861 is a worldwide phenomenon (Kaplan 2004). Horse strongyles resistant to benzimidazoles (BZ) and tetrahydropyrimidines (Pyrantel salt - PYR) are well known (Traversa et al. 2009, Kaplan and Nielsen 2010). The efficacy of macrocyclic lactones (ML) against horse strongyles is high (Lyons et al. 2008) and for the moment it is the only alternative available. Cases of cyathostomins resistant to ML have been described in both horses and donkeys (Trawford et al. 2005). However, there is no published study on the current situation of horse strongyles resistant to the anthelmintics commonly used in Romania. According to the National Sanitary Veterinary and Food Safety Authority in Romania, there were 344925 horses in Romania in 2011. The majority of those (98\%) were bred in small individual farms in rural areas, whereas the remainder in 44 stud farms. In the period of our study, 12 drugs containing BZ, tetrahydropyrimidines, ML (Iver- mectin - VM and Moxidectin - MOX) and combinations of those were registered for the treatment against horse strongyles in Romania.

According to the information provided by the veterinary practitioners, the most used anthelmintics in horses at the beginning of the 1990s were BZ-based drugs, especially Albendazole (ABZ), Mebendazole (MBZ) and Fenbendazole (FBZ), due to their efficacy and relatively low price compared to ML based drugs. This trend was maintained for over 15 years, but after this period ML-based anthelmintic drugs, especially IVM, started to be more frequently used. In contrast, there is no legal obligation to perform these treatments, nor treatment efficacy controls. Furthermore, there are also no protocols for the periodical change of the drug classes. Veterinary practitioners recommend the use of anthelmintic products in horses two to three times per year, in spring and in autumn, and possibly another dose in June-July. Some owners treat their horses by themselves, without resorting to veterinary expertise. As a result, they

Address for correspondence: M. Cernea, University of Agricultural Sciences and Veterinary Medicine, Faculty of Veterinary Medicine, Calea Mănăştur, no. 3-5, postal code 400372, Cluj-Napoca, Romania. Phone: +40 264596384/186; Fax: +40 264593792; E-mail: mihai.cernea@usamvcluj.ro 
use doses either higher or lower than specified, or products that are recommended for other species (bovines and sheep). The lack of a national strategy regarding the compulsory prevention and control programme concerning horse nematodes may influence the structure of the strongyle species and the development of multiple anthelmintic resistance (Kaplan 2002, Cernea et al. 2005).

The purpose of the present study was to investigate the presence and distribution of equid strongyles resistant to the anthelmintics used in Romania, as well as the pre- and post-treatment prevalence of strongyle species.

\section{MATERIALS AND METHODS}

\section{Study dates, locations and composition of the equid groups and subgroups}

The studies were performed in the period between 2010-2013, in 26 locations in 14 counties (Fig. 1). The total number of equids included in the study was 611 (of which 588 horses and 23 donkeys), which represent about $15 \%$ of the total equid population in the localities selected for this study (4 159 equids). The equids studied were aged between 1.5-19 years, of which 239 were males (including 19 stallions) and 372 were females.

Three groups of equids were formed depending on the locations in which the anthelmintics were used. The first group (I), consisting of subgroups 1-11 (Table 1), included 240 horses and 23 donkeys, which were treated with ABZ $5 \mathrm{mg} / \mathrm{kg}$ (Rombendazol 10\% - Romvac Company; Ecvipast N - Institute Pasteur). The second group (II), consisting of subgroups 12-23 (Table 1), included 267 horses which were treated with FBZ $7.5 \mathrm{mg} / \mathrm{kg}$ (Vanbendazol - Vanelli SRL; Panacur - Intervet). IVM was used in the third group (III) consisting of subgroups 24-26 (Table 1). These included 81 horses treated with doses of $0.2 \mathrm{mg} / \mathrm{kg}$ (Equirom I - Romvac Company; Equimectin - Kepro BV; Eqvamec P - Pasteur Filiala Filipeşti). Before treatment, all equids were weighted and the appropriate dose of anthelmintic was administered to them by the veterinary practitioner.

The equids included in the study belonged to private individual farms (owners), with a single subgroup (No. 26) belonging to a private stud farm. Based on anamnesis and information provided by the veterinary practitioners, previous anthelmintic treatments with ABZ, FBZ and IVM-based drugs, were administered with minimum 3 month before this study (Table 1). Consequently, the criterion of group formation was the owner's acceptance of the protocol, as well as the actual possibility of faeces' sampling, both pre-treatment and post-treatment.

\section{Anthelmintic resistance studies}

The resistance to anthelmintic drugs was established using the Faecal Egg Count Reduction Test (FECRT) (Coles et al. 1992). Faecal samples (200 g/sample) were collected on the same day, before drug administration, as well as 14 days post-treatment. Number of eggs per gram (EPG) was measured using the McMaster method with a 25 eggs per gram sensitivity (Herd 1992). The arithmetic mean and prevalence of pre-treatment (Pre) and post-treatment (Post) strongyle parasitism was calculated based on EPG. The efficacy of the anthelmintic treatment was calculated based on the pre-treatment and post-treatment results obtained using FECRT, according to the following equation:

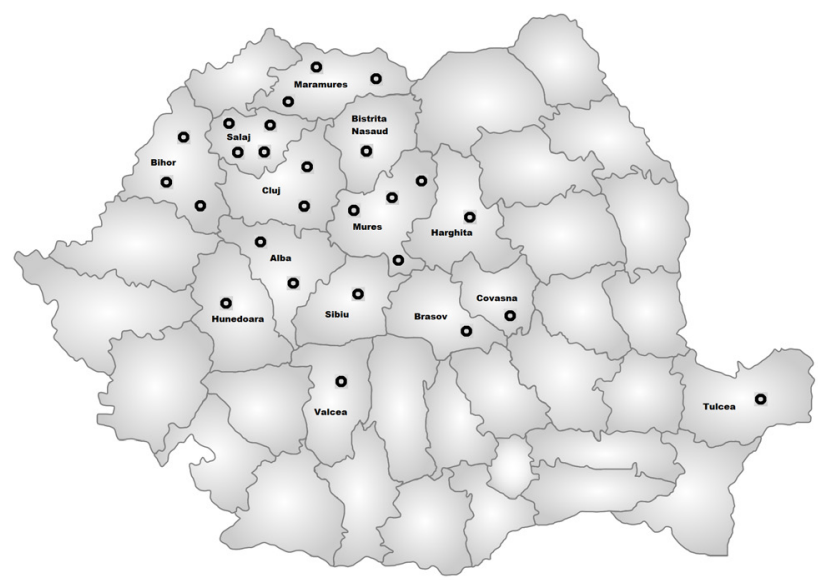

Fig 1. Geographic location of the 26 Romanian farms/localities involved in the screening study.

FECR $=100 \times[(1-$ FEC Post $) /($ FEC Pre $)]$

The $95 \%$ confidence interval (CI 95\%) as well as the lower confidence level (LCL) have been determined. The results obtained using FECRT have been interpreted based on the faecal egg reduction percentage, as well as on the lower limit of the $95 \%$ confidence interval (LCL 95\%). In accordance with the methods recommended by the World Association for the Advancement of Veterinary Parasitology for the detection of anthelmintic resistance in horses and ruminants (Coles et al. 1992):

resistance is present (R) if FECR $<90 \%$ and the LCL 95\% $<90 \%$;

resistance is suspected (S) if FECR $\geq 90 \%$ and/or LCL 95\% $<90 \%$;

no resistance $(\mathrm{N})$ if FECR $\geq 90 \%$ and LCL $95 \%>90 \%$.

\section{Species-specific identification of equid strongyles based on the morphology of third stage larvae}

Species-specific identification of equid strongyles and implicitly of the resistant species was determined based on the means of the larval cultures both pre-treatment and post-treatment. The cultures for larval counts have been designed using $100 \mathrm{~g}$ of faeces incubated for 12 days at $27^{\circ} \mathrm{C}$ at an $80 \%$ relative humidity. Subsequently, the larval cultures have been baermannised for ten hours. The sediment has been collected in separate tubes, to which $100 \mathrm{ml}$ of distilled water was added. After mixing, $0.1 \mathrm{ml}$ of material was collected with a micropipette. The liquid phase was examined under the microscope, using a $20 \times$ objective. The number of larvae per gram (LPG) was obtained by multiplying the number of the counted larvae by a factor of ten (Nielsen et al. 2010). The strongyle species/families have been identified based on the third larval stage (L3) morphology (Cernea et al. 2008, Madeira de Carvalho et al. 2008, Kornaś et al. 2009). Depending on the number of larvae in each sample, between 5-100 larvae per sample were identified and the results were expressed as a percentage.

\section{Statistical analysis}

The statistical significance of the data was determined by comparing post-treatment and pre-treatment results (ANOVAunpaired $t$ test - Welch/GraphPad InStat Inc., version 3.10). The 
Table 1. Groups, subgroups, location, number of equids from the various farms included in the present study, frequency and type of previous treatments and anthelmintics tested.

\begin{tabular}{|c|c|c|c|c|c|c|c|}
\hline \multirow{2}{*}{$\begin{array}{l}\text { Group no. and } \\
\text { drug tested }\end{array}$} & \multirow{2}{*}{$\begin{array}{l}\text { Subgroup } \\
\text { no. }\end{array}$} & \multirow{2}{*}{ County/locality } & \multirow{2}{*}{$\begin{array}{l}\text { Total no. of } \\
\text { equids }\end{array}$} & \multirow{2}{*}{\multicolumn{2}{|c|}{$\begin{array}{l}\text { Frequency of anthelmintic treatments and } \\
\text { medication previously used Bottom of Form }\end{array}$}} & \multicolumn{2}{|c|}{ Tested equids } \\
\hline & & & & & & No. & $\%$ from total \\
\hline \multirow{11}{*}{ I ABZ } & 1 & Alba/Abrud & 136 & once a year & $\mathrm{ABZ}, \mathrm{FBZ}$ & 30 & 22 \\
\hline & 2 & Alba/Micesti & 161 & once a year & $\mathrm{ABZ}$ & 10 & 6 \\
\hline & 3 & Bihor/Beznea & 407 & once a year & $\mathrm{ABZ}$ & 33 & 8 \\
\hline & 4 & Bistrita Nasaud/Ilva Mare & 382 & twice a year & ABZ, FBZ, ML & 53 & 14 \\
\hline & 5 & Brasov/Poiana Marului & 176 & once a year & $\mathrm{ABZ}$ & 19 & 11 \\
\hline & 6 & Covasna/Ilieni & 68 & twice a year & ABZ, ML & 12 & 18 \\
\hline & 7 & Mures/Panet & 201 & once a year & $\mathrm{ABZ}$ & 25 & 12 \\
\hline & 8 & Mures/Tonciu & 49 & once a year & $\mathrm{ABZ}$ & 16 & 33 \\
\hline & 9 & Sălaj/Almaşului ${ }^{(1)}$ & 98 & no treatments & - & 23 & 23 \\
\hline & 10 & Sălaj/Criseni & 78 & once a year & $\mathrm{ABZ}$ & 11 & 14 \\
\hline & 11 & Sibiu/Arpasul de Sus & 278 & once a year & ABZ, FBZ, ML & 31 & 11 \\
\hline \multirow{12}{*}{ II FBZ } & 12 & Bihor/Nojorid & 308 & twice a year & FBZ, ML & 30 & 10 \\
\hline & 13 & Cluj/Salicea & 159 & twice a year & $\mathrm{ABZ}, \mathrm{FBZ}$ & 24 & 15 \\
\hline & 14 & Cluj/Someseni & 193 & twice a year & FBZ, ML & 21 & 11 \\
\hline & 15 & Hunedoara/Pestisul Mic & 118 & once a year & $\mathrm{ABZ}, \mathrm{FBZ}$ & 17 & 14 \\
\hline & 16 & Maramures/Salsig & 188 & once a year & ML, FBZ & 23 & 12 \\
\hline & 17 & Maramures/Satu Lung & 122 & once a year & FBZ, ML & 16 & 13 \\
\hline & 18 & Maramures/Viseul de Sus & 121 & once a year & FBZ & 28 & 23 \\
\hline & 19 & Mures/Breaza & 69 & once a year & FBZ & 33 & 48 \\
\hline & 20 & Mures/Voievodeni & 173 & once a year & FBZ, ABZ & 18 & 10 \\
\hline & 21 & Sălaj/Jibou & 83 & once a year & FBZ & 9 & 11 \\
\hline & 22 & Sălaj/Meseseni de Jos & 89 & once a year & ABZ, FBZ & 28 & 31 \\
\hline & 23 & Valcea/Lapusna & 83 & once a year & FBZ & 20 & 24 \\
\hline \multirow{4}{*}{ III IVM } & 24 & Bihor/Osorhei & 205 & twice a year & FBZ, ML & 30 & 15 \\
\hline & 25 & Harghita/Gheorgheni & 188 & twice a year & FBZ, ML & 25 & 13 \\
\hline & 26 & Tulcea/Tulcea $^{(2)}$ & 26 & three times a year & ML, $\mathrm{PYR}^{(3)}$ & 26 & 100 \\
\hline & & Total & 4159 & & & 611 & 15 \\
\hline
\end{tabular}

ABZ - Albendazole; FBZ - Fenbendazole; IVM - Ivermectin; ML - Macrocyclic Lactones; ${ }^{(1)}$ donkeys; ${ }^{(2)}$ horse stud farm; ${ }^{(3)}$ combination of Ivermectin and Pyrantel (PYR).

comparison was performed for each anthelmintic drug, the measured parameter being the prevalence.

\section{RESULTS}

\section{Anthelmintic resistance distribution}

In the case of ABZ treatments (Table 2), the reduction of the prevalence and intensity was significant in the posttreatment stage $(\mathrm{P}<0.001)$. The ABZ resistance phenomenon was established in nine of the subgroups $(82 \%)$ by means of the EPG quantification.

Fenbendazole treatment (Table 2) resulted in a significant reduction $(\mathrm{P}<0.001)$ in the prevalence and intensity of strongyle parasitism, even though resistance was present in nine $(75 \%)$ out of the 12 subgroups of treated horses. Resistance has been suspected in only one subgroup (No. 21 ) of horses $(8 \%)$. FBZ was efficient against strongyles (17\%) only in two horse subgroups (Nos. 12 and 13).

The results of this study have shown that the strongyles resistant to $\mathrm{ABZ}$ and $\mathrm{FBZ}$ in the studied equid groups are widespread. The ABZ- or FBZ-resistant strongyles were found in the horse subgroups that were treated once per year. ABZ-resistant strongyles have been identified in the donkey subgroup (No. 9 - Sălaj/Almaşului), even though the animals did not benefit from treatments. This fact reveals that untreated animals run a risk of contamination with resistant strongyle species and outlines the neces- sity of simultaneous treatments of all animals in a certain equid population. Otherwise, untreated animals may constitute a reservoir of resistant strongyles. The situation of the 23 horse subgroups (from 1-23) that were treated with $\mathrm{ABZ}$ and FBZ appears to be similar.

Ivermectin (Table 2) has induced an important drop $(\mathrm{P}<0.01)$ of the two investigated parameters (prevalence and intensity). The strongyle populations in the horse group (III) treated with IVM-based drugs were affected in a high proportion. The reduction percentage mean of EPG was $99 \%$, with an LCL $95 \%$ of $97-100 \%$. Therefore, the strongyles in the IVM-treated horses have not developed resistance. The mean prevalence of strongyle infection dropped significantly 14 days after treatment $(8 \%)$. The relative recent and limited use of IVM in Romania, as well as its different mechanism of action (increased the release of gamma-Aminobutyric acid (GABA) from synaptosomes of the nervous system and interference with the reproduction of nematode parasites) compared with BZ allowed this drug to remain highly efficient against strongyles and cyathostomines in the horses included in the study.

\section{Species-specific identification of equid strongyles}

A total number of 37882 larvae were identified from 611 larval cultures in the pre-treatment stage and 17719 larvae from the same number of larval cultures in the post-treatment stage. The mean number of larvae identi- 
Table 2. Results of faecal egg count reduction test and prevalence of strongyle parasitism based on number of eggs per gram, after horse treatment with Albendazole (ABZ group no. I), Fenbendazole (FBZ group no. II) and Ivermectin (IVM group no. III).

\begin{tabular}{|c|c|c|c|c|c|c|c|c|}
\hline \multirow{2}{*}{ Group no. } & \multirow{2}{*}{ Subgroup no. } & Mean EPG & Prevalence $(\%)$ & Mean EPG & Prevalence $(\%)$ & \multirow{2}{*}{$\begin{array}{c}\text { FECRT } \\
(\%)\end{array}$} & \multirow{2}{*}{$\begin{array}{l}\text { LCL } \\
95 \%\end{array}$} & \multirow{2}{*}{ Result } \\
\hline & & \multicolumn{2}{|c|}{0 day } & \multicolumn{2}{|c|}{14 days } & & & \\
\hline \multirow{14}{*}{ I ABZ } & 1 & 1843 & 93 & 293 & 73 & 84 & 76 & $\mathrm{R}$ \\
\hline & 2 & 720 & 80 & 95 & 50 & 87 & 44 & $\mathrm{R}$ \\
\hline & 3 & 1803 & 97 & 520 & 64 & 71 & 67 & $\mathrm{R}$ \\
\hline & 4 & 1676 & 77 & 55 & 19 & 97 & 92 & $\mathrm{~N}$ \\
\hline & 5 & 2216 & 100 & 268 & 53 & 88 & 73 & $\mathrm{R}$ \\
\hline & 6 & 496 & 67 & 13 & 25 & 97 & 91 & $\mathrm{~N}$ \\
\hline & 7 & 1210 & 88 & 454 & 32 & 62 & 9 & $\mathrm{R}$ \\
\hline & 8 & 1228 & 94 & 134 & 44 & 89 & 70 & $\mathrm{R}$ \\
\hline & 9 & 1865 & 100 & 267 & 83 & 86 & 70 & $\mathrm{R}$ \\
\hline & 10 & 2473 & 100 & 473 & 73 & 81 & 41 & $\mathrm{R}$ \\
\hline & 11 & 1316 & 97 & 195 & 58 & 85 & 84 & $\mathrm{R}$ \\
\hline & SD & 603 & 11 & 174 & 21 & 10 & - & - \\
\hline & Mean & 1532 & 90 & 251 & 52 & 84 & 65 & - \\
\hline & Result & & & & & & & $\mathrm{R}=82 \% ; \mathrm{S}=0 \% ; \mathrm{N}=18 \%$ \\
\hline \multirow{15}{*}{ II FBZ } & 12 & 1320 & 87 & 15 & 3 & 99 & 90 & $\mathrm{~N}$ \\
\hline & 13 & 523 & 71 & 6 & 13 & 99 & 96 & $\mathrm{~N}$ \\
\hline & 14 & 636 & 81 & 174 & 33 & 73 & 37 & $\mathrm{R}$ \\
\hline & 15 & 847 & 82 & 221 & 59 & 74 & 49 & $\mathrm{R}$ \\
\hline & 16 & 1691 & 100 & 346 & 65 & 80 & 44 & $\mathrm{R}$ \\
\hline & 17 & 1366 & 75 & 150 & 31 & 89 & 54 & $\mathrm{R}$ \\
\hline & 18 & 857 & 82 & 93 & 32 & 89 & 78 & $\mathrm{R}$ \\
\hline & 19 & 1012 & 91 & 106 & 70 & 89 & 68 & $\mathrm{R}$ \\
\hline & 20 & 697 & 72 & 72 & 11 & 89 & 51 & $\mathrm{R}$ \\
\hline & 21 & 1994 & 89 & 189 & 44 & 90 & 56 & S \\
\hline & 22 & 2205 & 93 & 282 & 32 & 87 & 80 & $\mathrm{R}$ \\
\hline & 23 & 930 & 65 & 345 & 85 & 63 & -177 & $\mathrm{R}$ \\
\hline & SD & 547 & 10 & 116 & 25 & 11 & - & - \\
\hline & Mean & 1173 & 82 & 167 & 40 & 85 & 44 & - \\
\hline & Result & & & & & & & $\mathrm{R}=75 \% ; \mathrm{S}=8 \% ; \mathrm{N}=17 \%$ \\
\hline \multirow{6}{*}{ III IVM } & 24 & 794 & 87 & 5 & 7 & 99 & 97 & $\mathrm{~N}$ \\
\hline & 25 & 2474 & 92 & 20 & 12 & 99 & 98 & $\mathrm{~N}$ \\
\hline & 26 & 548 & 69 & 2 & 4 & 100 & 100 & $\mathrm{~N}$ \\
\hline & SD & 1048 & 12 & 10 & 4 & 0.23 & - & - \\
\hline & Mean & 1272 & 83 & 9 & 8 & 99 & 98 & - \\
\hline & Result & & & & & & & $R=0 \% ; S=0 \% ; N=100 \%$ \\
\hline
\end{tabular}

ABZ - Albendazole; FBZ - Fenbendazole; IVM - Ivermectin; ; FECRT - Faecal Egg Count Reduction Test; LCL - lower confidence level; N - no resistance; $\mathrm{R}$ - resistance; $\mathrm{S}$ - suspected.

fied per sample was 46. The larval culture method allowed the identification of the third stage larvae (L3); thus, we were able to establish the identification of strongyle species with reasonable accuracy. The following species of the subfamily Strongylinae Müller, 1780 were identified: Strongylus vulgaris Looss, 1900, Strongylus equinus (Müller, 1780), Strongylus edentates Looss, 1900, Craterostomum acuticaudatum Kotlán, 1919, Oesophagodontus robustus Giles, 1892, and several species of Triodontophorus Looss, 1900. Regarding nematodes of the subfamily Cyathostominae Molin, 1861, the following species were identified: Gyalocephalus capitatus (Looss, 1900), species of Poteriostomum Quiel, 1919 and Cyathostominae gen. sp. Third-stage larvae of cyathostomine nematodes were divided to subtypes $\mathrm{A}-\mathrm{H}$ according to the number, morphology and alignment of their intestinal cells (Cernea et al. 2008). Cyathostomum A has 8 intestinal cells, the first two parallel (triangular or rectangular), the remaining six in a single row (trapezoidal or rectangular). Cyathostomum $\mathrm{B}$ has 8 intestinal cells, triangular or pentagonal shaped, arranged in double row. Cyathostomum $\mathrm{C}$ has 8 intestinal cells, first 4 in a double row (pentagonal, triangular or rectangular shaped), the remaining in a single row (trapezoidal). Cyathostomum D has 8 intestinal cells, triangular or trapezoidal shaped, arranged in a single row. Cyathostomum $\mathrm{E}$ has 6 intestinal cells poorly defined, triangular or trapezoidal shaped, with variable display. Cyathostomum $\mathrm{F}$ has 7 intestinal triangular and trapezoidal elongated cells, with variable display. Cyathostomum $\mathrm{G}$ has 8 intestinal cells, triangular and/or rectangular (elongated and thin), trapezoidal (distal part), which set is variable. Cyathostomum $\mathrm{H}$ has 9 intestinal cells, triangular and elongated, the first 6 in double row and the others in a single row.

The pre-treatment prevalence of cyathostomine nematodes was $78.3 \%$ (Table 3 ). We could identify G. capitatus (prevalence of 3.3\%) and species of Poteriostomum (9.0\%) as well as six other morphological types of third-stage larvae of cyathostomine nematodes, namely type $\mathrm{A}-51.1 \%$, type $\mathrm{B}-0.8 \%$, type $\mathrm{C}-10.3 \%$, type $\mathrm{D}-3.4 \%$ and type $\mathrm{E}$, F, $\mathrm{G}$ and $\mathrm{H}-0.5 \%$. Six species of the subfamily Strong- 
Table 3. Pre-treatment (Pre) and post-treatment (Post) mean prevalence (\%) \pm standard deviation (SD) and P-value of strongyle species found in the tested equids from 26 Romanian farms/localities.

\begin{tabular}{|c|c|c|c|c|c|c|c|c|c|c|}
\hline \multirow{3}{*}{ Species } & \multirow{2}{*}{\multicolumn{2}{|c|}{$\begin{array}{l}\text { Albendazole } \\
\text { (group no. I) } \\
526 \text { samples }\end{array}$}} & \multirow{2}{*}{\multicolumn{2}{|c|}{$\begin{array}{l}\text { Fenbendazole } \\
\text { (group no. II) } \\
534 \text { samples }\end{array}$}} & \multirow{2}{*}{\multicolumn{2}{|c|}{$\begin{array}{l}\text { Ivermectin } \\
\text { (group no. III) } \\
162 \text { samples }\end{array}$}} & \multirow{2}{*}{\multicolumn{2}{|c|}{$\begin{array}{c}\text { General } \\
\text { mean per } \\
\text { species }\end{array}$}} & \multirow{2}{*}{\multicolumn{2}{|c|}{$\begin{array}{c}\text { General } \\
\text { mean per } \\
\text { subfamily }\end{array}$}} \\
\hline & & & & & & & & & & \\
\hline & Pre & Post & Pre & Post & Pre & Post & Pre & Post & Pre & Post \\
\hline \multicolumn{11}{|l|}{ Strongylinae } \\
\hline $\begin{array}{l}\text { Craterostomum acuticaudatum } \\
\mathrm{P}\end{array}$ & $\begin{array}{c}1.7 \pm 1.6 \\
0.1748\end{array}$ & $0.8 \pm 1.2$ & $\begin{array}{c}2.3 \pm 1.4 \\
0.0733\end{array}$ & $1.2 \pm 1.5$ & $0.8 \pm 0.8$ & 0 & 1.6 & 0.7 & \multirow{6}{*}{22} & \multirow{6}{*}{5.4} \\
\hline $\begin{array}{l}\text { Oesophagodontus robustus } \\
\mathrm{P}\end{array}$ & $\begin{array}{l}3.5 \pm 1.6 \\
<0.0001\end{array}$ & $0.5 \pm 0.9$ & $\begin{array}{c}6.0 \pm 2.9 \\
0.0004\end{array}$ & $1.7 \pm 2.1$ & $5.7 \pm 3.2$ & 0 & 5.0 & 0.7 & & \\
\hline $\begin{array}{l}\text { Strongylus edentatus } \\
\mathrm{P}\end{array}$ & $\begin{array}{c}2.2 \pm 1.9 \\
0.0118\end{array}$ & $0.5 \pm 0.9$ & $\begin{array}{c}2.7 \pm 1.8 \\
0.0010\end{array}$ & $0.5 \pm 0.9$ & $1.4 \pm 2.4$ & 0 & 2.1 & 0.3 & & \\
\hline Strongylus equinus & $0.1 \pm 0.4$ & 0 & $0.1 \pm 0.2$ & 0 & 0 & 0 & 0.1 & 0 & & \\
\hline $\begin{array}{l}\text { Strongylus vulgaris } \\
\mathrm{P}\end{array}$ & $\begin{array}{c}12.6 \pm 3.5 \\
<0.0001\end{array}$ & $2.4 \pm 2.5$ & $\begin{array}{l}11.2 \pm 3.2 \\
0.0002\end{array}$ & $4.3 \pm 4.3$ & $7.1 \pm 1.1$ & 0 & 10.3 & 2.2 & & \\
\hline $\begin{array}{l}\text { Triodontophorus species } \\
\mathrm{P}\end{array}$ & $\begin{array}{l}2.9 \pm 2.2 \\
0.0423\end{array}$ & $1.2 \pm 1.6$ & $\begin{array}{c}2.5 \pm 1.5 \\
0.7282\end{array}$ & $2.8 \pm 2.9$ & $\begin{array}{c}2.1 \pm 1.6 \\
0.0938\end{array}$ & $0.1 \pm 0.12$ & 2.5 & 1.3 & & \\
\hline \multicolumn{11}{|l|}{ Cyathostominae } \\
\hline $\begin{array}{l}\text { Cyathostomine nematodes subtypes A-H } \\
\text { P }\end{array}$ & $\begin{array}{l}65.6 \pm 6.6 \\
<00001\end{array}$ & $89.9 \pm 6.0$ & $\begin{array}{c}62.9 \pm 6.1 \\
<0.0001\end{array}$ & $86.1 \pm 8.3$ & $\begin{array}{c}69.4 \pm 6.4 \\
0.0012\end{array}$ & $99.7 \pm 0.42$ & 66.0 & 91.9 & & \\
\hline $\begin{array}{l}\text { Gyalocephalus capitatus } \\
\mathrm{P}\end{array}$ & $\begin{array}{c}2.5 \pm 2.9 \\
0.0819\end{array}$ & $0.9 \pm 1.0$ & $\begin{array}{c}4.6 \pm 4.5 \\
0.0227\end{array}$ & $1.1 \pm 1.9$ & $\begin{array}{c}2.7 \pm 1.6 \\
0.0633\end{array}$ & $0.3 \pm 0.46$ & 3.3 & 0.8 & 78.3 & 94.7 \\
\hline $\begin{array}{l}\text { Poteriostomum spp. } \\
\text { P }\end{array}$ & $\begin{array}{c}8.7 \pm 3.7 \\
0.0072\end{array}$ & $3.7 \pm 4.2$ & $\begin{array}{l}7.6 \pm 3.5 \\
<0.0001\end{array}$ & $2.2 \pm 1.9$ & $10.8 \pm 5.5$ & 0 & 9.0 & 2.0 & & \\
\hline
\end{tabular}

$\mathrm{P}<0.05$ - significant; $\mathrm{P}<0.01$ - very significant; $\mathrm{P}<0.001$ - extremely significant.

ylinae were identified, with a prevalence of $22 \%$, the most frequent being Strongylus vulgaris (10.3\%) (Table 3).

Fourteen days after the completion of the anthelmintic treatment, the species structure has altered depending on the horse group studied, on the drug used and on its efficacy (Table 3). In general, strongyline nematodes were much more sensitive to the drug used. The post-treatment prevalence of this subfamily was $5.4 \%$, the reduction being highly significant in the IVM treated horse group (III), where only larvae of species of Triodontophorus were identified $(0.1 \%)$. The most sensitive to all the drugs used was $S$. equinus, which disappeared from all of the examined samples. Strongylus vulgaris proved to be the most resistant to all ABZ- and FBZ-based drugs. The post-treatment prevalence of cyathostomine nematodes was $94.7 \%$, representing especially ABZ- and FBZ-based anthelmintic resistant species. Small strongyles including cyathostomines proved to be the most resistant, their prevalence being $91.9 \%$, of which type A represented $77.3 \%$, type B $-2.8 \%$, type $\mathrm{C}-6.8 \%$, type $\mathrm{D}-4.3 \%$ and types $\mathrm{E}-\mathrm{H} 0.7 \%$. In the IVM treated horse group (III), we could identify only a small number of $G$. capitatus $(0.8 \%)$ and species of $P o-$ teriostomum (2.0\%) as well as third-stage larvae of type A (83.3\%) and $\mathrm{C}(8.6 \%)$.

In general, the post-treatment decrease of the prevalence was statistically significant (Table 3 ) in the species of the Strongylinae, which shows good efficacy of the treatment with ABZ, FBZ and especially with IVM. Nevertheless, there was a significant increase in the prevalence of the infestation with cyathostomine nematodes, which demonstrates the resistance of these species to ABZ and FBZ.

\section{DISCUSSION}

The studies conducted all over the world in the past 23 years have revealed an increase of the prevalence of cyathostomine nematodes as well as a decrease of the prevalence of large strongyles (Kaplan 2002, Kuzmina and Kharchenko 2008, Traversa et al. 2012).

Regardless of the BZ resistance quantification method employed, the values obtained in this study are close to those found in other European countries, where the prevalence of resistant strongyles, especially that of cyathostomins, is over $70 \%$ (Wirtherle et al. 2004, Traversa et al. 2007). In the absence of previous data on the situation in Romania and based on the data available in the literature (Kaplan 2002), we can assume that resistance of strongyles to BZs occurred due to their prolonged and exclusive use, and sometimes even to their irrational use, beyond the limits and conditions stipulated by the producer (overdosage/ underdosage) (Conder and Campbell 1995).

Despite the fact that between 2005-2009, the use of BZs in horses was significantly reduced, being reinstated only in the last three or four years, the resistant strongyle species have not disappeared, a phenomenon that has been mentioned in other studies as well (Osterman Lind et al. 2007, Lyons et al. 2007). It has not yet been demonstrated that it is possible to re-establish the efficacy of a drug category to which a certain level of resistance had previously existed, even if these drugs were not used for a given period of time (Slocombe et al. 2008, von Samson-Himmelstjerna 2012).

However, in terms of anthelmintic resistance, the control of this phenomenon must be based on, and adapted to, the specificity of each individual horse group. This would 
depend on the drug molecule and frequency of the treatments, the selection of the anthelmintic drug based on the results of the efficacy tests, the age of the animals, pasture hygiene and management (Francisco et al. 2012, von Samson-Himmelstjerna 2012). The study completed in Romania on the 26 equid subgroups reveals the possibility that this phenomenon could be the result of the anthelmintic drugs administered, to which nematodes of the subfamily Strongylinae are much more sensitive (especially to IVM) than members of the Cyathostominae.

The current situation in Romania is due, to a large extent, to the lack of a clear and sustained nematode control programme in equids. Moreover, the clinical symptoms in massive infections with cyathostomines are neither obvious nor specific (Love et al. 1999) and thus the horse owners do not request anthelmintic treatments. In order to monitor the present situation of strongyles resistant to the anthelmintic drugs currently and commonly used in Ro- mania, a nation-wide programme should be implemented. This should include: (i) periodic epidemiological studies to accurately establish their intensity and prevalence; (ii) the onset of prophylactic and specific treatments, according to FECRT test results; (iii) therapeutic programmes correlated with the identified species; (iv) treatment of the entire group of horses, wherever resistant strongyles are identified; (v) education of horse owners; (vi) vet prescription based acquisition of the anthelmintics (Nielsen et al. 2006); and (vii) pasture hygiene and management skills optimisation in order to reduce the rate of re-infection (Nielsen 2012).

Acknowledgements. The authors would like to thank all the farmers and veterinary practitioners who willingly collaborated in this study. The study was funded by the University of Agricultural Sciences and Veterinary Medicine, Faculty of Veterinary Medicine, Cluj-Napoca, Romania - Internal competition for research grants in 2013, Human Resources-ISI, No. 1350/2013.

\section{REFERENCES}

Cernea M., Cozma V., Cernea C. 2005: In vivo testing of horse strongyles resistance to albendazole and mebendazole. Rev. Scientia Parasitol. 6: 89-95.

Cernea M., Madeira de Carvalho L.M., Cozma V., Cernea L.C., Răileanu Ş., Silberg R., Gut, A. 2008: Atlas of diagnosis of Equine Strongylidosis. AcademicPres, Cluj-Napoca, pp. 75-110.

Coles G.C., Bauer C., Borgsteede F.H.M., Geerts S., Klei T.R., TAYlor M.A., WAller P.J. 1992: World Association for the Advancement of Veterinary Parasitology (WAAVP) methods for the detection of Anthelmintic resistance in nematodes of veterinary importance. Vet. Parasitol. 44: 35-44.

Conder G.A., Campbell W.C. 1995: Chemotherapy of nematode infections o veterinary importance, with special reference to drug resistance. Adv. Parasitol. 35: 1-84.

Francisco R., Paz-Silva A., Francisco I., Cortiñas F.J., Miguélez S, Suárez J., Cazapal-Monteiro C.F., Suárez J.L., Arias M.S., SÁnchez-Andrade R. 2012: Preliminary analysis of the results of selective therapy against Strongyles in pasturing horses. J. Equine Vet. Science 32: 274-280.

Herd R.P. 1992: Performing equine fecal egg counts. Vet. Med. 87: $240-244$

KAPLAN R.M. 2002: Anthelmintic resistance in nematodes of horses. Vet. Res. 33: 491-507.

KAPLAN R.M. 2004: Drug resistance in nematodes of veterinary importance: a status report. Trends Parasitol. 20: 477-481.

Kaplan R.M., Nielsen, M.K. 2010: An evidence-based approach to equine parasite control: It ain't the $60 \mathrm{~s}$ anymore. Equine Vet. Educ. 22: 306-316.

Kornaś S., Gawor J., Cabaret J., Molenda K., Skalska M. Nowosad B. 2009: Morphometric identification of equid cyathostome (Nematoda: Cyathostominae) infective larvae. Vet. Parasitol. 162: 290-294.

Kuzmina T.A., Kharchenko V.O. 2008: Anthelmintic resistance in cyathostomins of brood horses in Ukraine and influence of anthelmintic treatments on strongylid community structure. Vet. Parasitol. 154: 277-288.

Love S., Murphy D., Mellor D. 1999: Pathogenicity of cyathostome infection. Vet. Parasitol. 85: 113-121.

Lyons E.T., Tolliver S.C., Ionita M., Lewellen A., Collins S.S. 2008: Field studies indicating reduced activity of ivermectin on small strongyles in horses on a farm in Central Kentucky. Parasitol. Res. 103: 209-215.

Lyons E.T., Tolliver S.C., Rathgeber R.A., Collins S.S. 2007: Parasite field study in central Kentucky on thoroughbred foals (born in 2004) treated with pyrantel tartrate daily and other parasiticides periodically. Parasitol. Res. 100: 473-478.

Madeira de Carvalho L.M., Cernea M., Martins S., Sousa S., Gersão S., Cernea L.C. 2008: Comparative study of cyathostomin horse infection in Portugal and Romania based in L3 subpopulations of Cyathostomum sensu latum. Scientia Parasitol. 2: $48-56$

NiELSEN M.K. 2012: Sustainable equine parasite control: perspectives and research needs. Vet. Parasitol. 185: 32-44.

Nielsen M.K., Baptiste K.E., Tolliver S.C., Collins S.S., Lyons E.T. 2010: Analysis of multiyear studies in horses in Kentucky to ascertain whether counts of eggs and larvae per gram of feces are reliable indicators of numbers of strongyles and ascarids present. Vet. Parasitol. 174: 77-84.

Nielsen M.K., Monrad J., Olsen S.N. 2006: Prescription-only anthelmintics - a questionnaire survey of strategies for surveillance and control of equine strongyles in Denmark. Vet. Parasitol. 135: 47-55.

Osterman Lind E., Kuzmina T., Uggla A., Waller P.J., Hoglund J. 2007: A field study on the effect of some anthelmintics on cyathostomins of horses in Sweden. Vet. Res. Commun. 31: 53-65.

von Samson-Himmelstjerna G. 2012: Anthelmintic resistance in equine parasites - detection, potential clinical relevance and implications for control. Vet. Parasitol. 185: 2-8.

von Samson-Himmelstjerna G., Fritzen B., Demeler J., Schurmann S., Rohn K., Schnieder T., Epe C. 2007: Cases of reduced cyathostomin egg-reappearance period and failure of Parascaris equorum egg count reduction following ivermectin treatment as well as survey on pyrantel efficacy on German horse farms. Vet. Parasitol. 144: 74-80.

Slocombe J.O., Cote J.F., De Gannes R.V. 2008: The persistence of benzimidazole-resistant cyathostomes on horse farms in Ontario over 10 years and the effectiveness of ivermectin and moxidectin against these resistant strains. Can. Vet. J. 49: 56-60.

Traversa D., Castagna G., von Samson-Himmelstjerna G., Meloni S., Bartolini R., Geurden T., Pearce C.M., Woringer E., Besognet B., Milillo P., D’Espois M. 2012: Efficacy of major anthelmintics against horse cyathostomins in France. Vet. Parasitol. 188: 294-300.

Traversa D., Iorio R., Otranto D., Giangaspero A., MililLO P., KLEI T.R. 2009: Species-specific identification of equine cyathostomes resistant to fenbendazole and susceptible to oxibendazole and moxidectin by macroarray probing. Exp. Parasitol. 121: 92-95. 
Traversa D., Klei T.R., Iorio R., Paoletti B., Lia R.P., Otranto D., Sparagano O.A., Giangaspero A. 2007: Occurrence of anthelmintic resistant equine cyathostome populations in central and southern Italy. Prev. Vet. Med. 82: 314-320.

Trawford A.F., Burden F., Hodgkinson J.E. 2005: Suspected moxidectin resistance in cyathostomes in two donkey herds at the Donkey Sanctuary, UK. In: Proceedings of the 20th Interna- tional Conference of the World Association for the Advancement of Veterinary Parasitology, Christchurch, New Zealand, 16-20 October 2005, p. 196.

Wirtherle N., Schnieder T., von Samson-Himmelstjerna G. 2004: Prevalence of benzimidazole resistance on horse farms in Germany. Vet. Rec. 154: 39-41.

Cite this article as: Cernea M., Cristina R.T., Ştefănuţ L.C., Madeira de Carvalho L.M., Taulescu M.A., Cozma V. 2015: Screening for anthelmintic resistance in equid strongyles (Nematoda) in Romania. Folia Parasitol. 62: 023. 